\title{
Georgiens frosne konflikt er tøet op
}

Af Ota Tiefenböck

I august er det syv år siden, at Georgien udkæmpede en kortvarig krig med Rusland. Krigen resulterede i, at landets hovedsageligt russisktalende provinser Sydossetien og Abkhasien for alvor rev sig løs fra Georgien og udråbte sig som selvstændige stater. Georgien mistede i løbet af nogle få dage næsten 20 pct. af sit territorium og nægter, i lighed med de fleste lande i verden, at anerkende provinsernes uafhængighed. Kun Rusland, Nicaragua og Venezuela har anerkendt Sydossetien og Abkhasien som suveræne stater, men verdens manglende anerkendelse ser ikke ud til at gøre større indtryk på udbryderprovinserne.

Konflikten omkring de to georgiske udbryderrepublikker bliver ofte sammenlignet med Transnistrien i Moldova og Nagorno-Karabakh i Aserbajdsjan/Armenien og betegnet som en frossen konflikt - og Donetsk og Luhansk i Ukraine ser ud til snart at komme i samme kategori.

Betegnelsen afspejler dog langtfra situationen i Sydossetien og Abkhasien, som til forskel for de andre nævnte konfliktområder fungerer som de facto selvstændige lande og nærmest som en integreret del af Den Russiske Føderation. Betegnelsen 'frossen konflikt' er derfor formentlig mere et udtryk for georgisk og vesteuropæisk ønsketænkning end en afspejling af realiteterne i den aktuelle situation.

\section{Tætte bånd til Rusland}

Både Abkhasien og Sydossetien har tætte bånd til Rusland og har på det seneste indgået en samarbejdsaftale med Rusland. For Abkhasiens vedkommende skete det i november sidste år og for Sydossetiens i marts i år. Det er formentlig ingen tilfældighed, at aftalerne med Rusland kommer kort efter, at Georgien har underskrevet en samarbejdsaftale, den såkaldte associeringsaftale, med EU. Ruslands samarbejdsaftale med republikkerne må derfor betragtes som landets svar på EU's associeringsaftale. Aftalerne betyder et tæet samarbejde på en lang række områder, hvoraf et af de vigtigste er et forsvarssamarbejde. Aftalerne betyder, at begge udbryderrepublikker nu har klare garantier for deres sikkerhed og dermed uafhængighed af Georgien.

Derudover betyder de, at Rusland har slået sin tilstedeværelse i regionen fast og, efter den russiske annektering af den ukrainske halvø Krim, nu har fået kontrol over en større del af Sortehavet. Et område, som har en stor strategisk betydning for Rusland. Rusland har desuden tropper udstationeret i Abkhasien og Sydossetien.

Ota Tiefenböck er journalist med speciale i Øst- og Centraleuropa, Balkan og Kaukasus. 


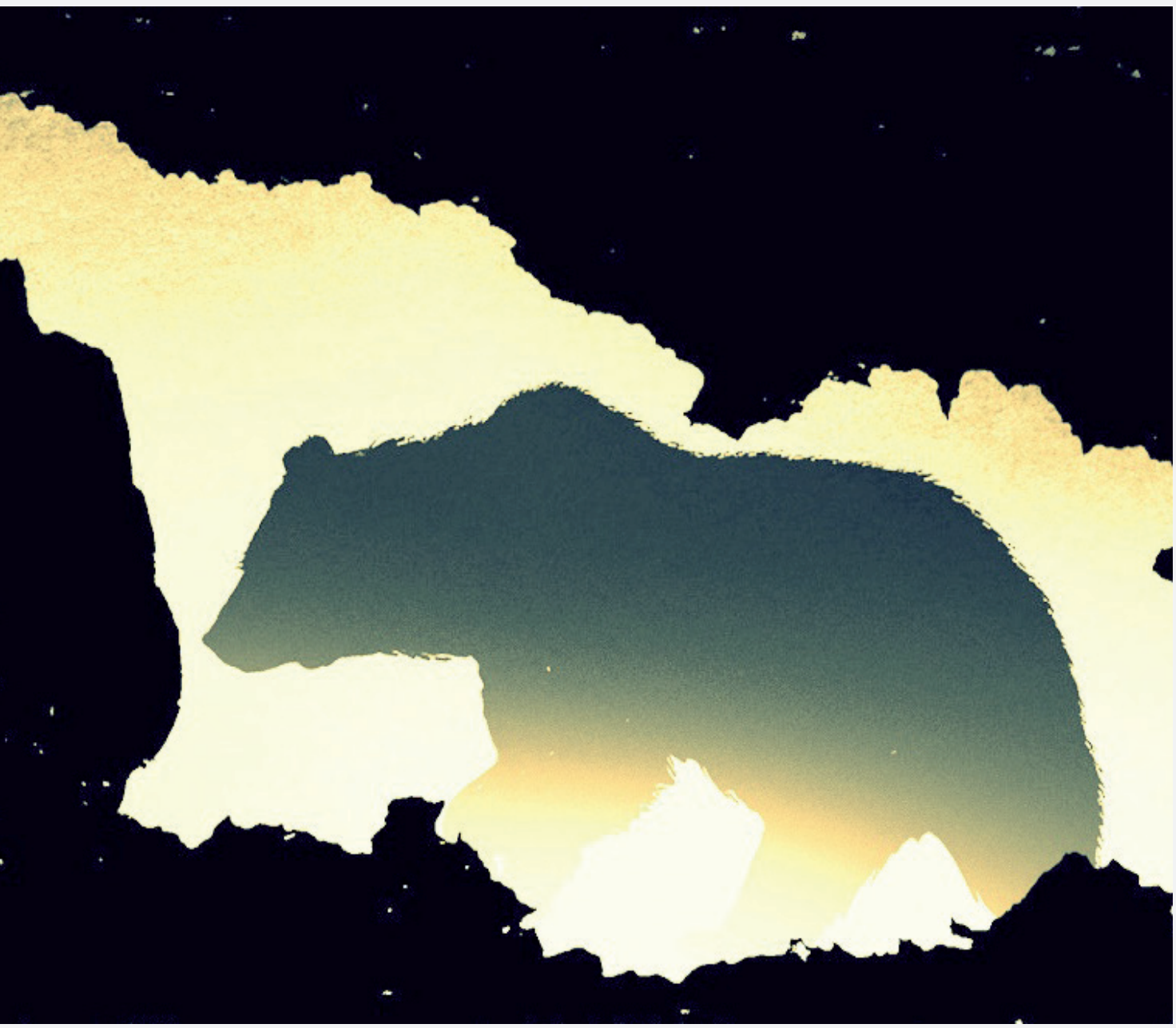

ILLUSTRATION: Project syndicate, 2015

Aftalerne med Rusland betyder også flere russiske investeringer i begge udbryderrepublikker og dermed stigende økonomisk afhængighed af Rusland. Der meldes allerede nu om store russiske op$\mathrm{k} ø \mathrm{~b}$ af jord- og ejendomme i især Abkhasien, som under Sovjetunionen var et populært ferieområde. Det er derfor nærmest et udtryk for utopisk tankegang at forestille sig, at republikkerne på noget tidspunkt kan komme på georgiske hænder igen.

Lederne i de to republikker, Leonid Tibilov fra Sydossetien og Raul Khadzhimba fra Abkhasien, afviser dog på nuværende tidspunkt, at republikkerne ønsker at blive optaget i Den Russiske Føderation.

En eventuel annektering af republikkerne har dog formentlig ikke større praktisk betydning, da republikkerne allerede nu fungerer som en integreret del af Den Russiske Føderation.

\section{De facto annektering}

De russiske aftaler med udbryderrepublikkerne vækker ikke megen begejstring hverken i Georgien eller hos Vesten. Her 
bliver begge republikker fortsat betragtet som okkuperet georgisk territorium.

Den georgiske regering har da også straks efter aftalerne blev underskrevet kaldt dem et seriøst skridt på vej mod russisk annektering af republikkerne. Det samme gælder NATO, som betragter aftalerne som en krænkelse af Georgiens territoriale integritet, og det russiske skridt har heller ikke fået pæne ord med på vejen fra $\mathrm{EU}$, som mener, at aftalerne skader forsøget på at stabilisere områdets regionale sikkerhed.

Hvorvidt de georgiske og vestlige fordømmelser af Ruslands aftaler med henholdsvis Abkhasien og Sydossetien hjælper på selve situationen i Kaukasus er ganske tvivlsomt. Aftalerne er nemlig et klart bevis på, at Vestens handlemuligheder i konflikten er ganske begrænsede, og at den georgiske integration i NATO og EU, som både EU og Georgien taler om og ønsker, mere er et udtryk for ønsketænkning end et realistisk billede af situationen. Denne kendsgerning hjælper umiddelbart heller ikke på de georgiske ambitioner for Sydossetien og Abkahasien og deres tilbagevenden til georgisk forvaltning.

\section{Ingen reelle tilbud fra EU...}

Georgien har i juni sidste år, sammen med Ukraine og Moldova, underskrevet en associeringsaftale med EU. Underskrivelsen må tolkes som et klart signal om, at Georgien, også under landets nye regering, ønsker orientering mod europæisk integration og de vestlige værdier. Den eftertragtede aftale har dog set med georgiske øjne kun bragt meget lidt med sig, og alt tyder på, at EU ikke har meget andet at tilbyde georgierne end løfter.

Aftalen med EU ser hverken ud til at føre til massive vestlige investeringer i landet, skabelse af nye arbejdspladser eller en bedre levestandard for georgierne.

Det er umiddelbart svært at forestille sig, at det på noget tidspunkt vil komme til det. Der er foreløbigt heller ikke sket forbedringer på mere jordnære områder som fx en aftale om visumfrihed med EU. Georgiske statsborgere skal fortsat have visum, hvis de vil rejse til EU, og det er umiddelbart tvivlsomt, om EU overhovedet er parat til at give Georgien en ordning om visumfrihed. Et af argumenterne imod den er netop eksistensen af udbryderrepublikkerne Sydossetien og Abkhasien, som betragtes som en potentiel fare.

Samme situation gør sig dog gældende i Moldova og landets udbryderregion Transnistrien, hvis eksistens ikke forhindrede en aftale om visumfrihed med EU.

\section{... eller fra NATO}

Situationen for Georgien ser ikke meget bedre ud i forhold til landets integration i NATO, som til trods for en række tilbud og aktiviteter fra NATOs side, herunder opbygning af et NATO træningscenter i Georgien, fortsat fastholder sin linje fra Bukarest-topmødet i 2008, hvor Georgien blev nægtet deltagelsen i den såkaldte MAP (Membership Actions Plan).

NATOs generalsekretær, Jens Stoltenberg mødtes med den georgiske premierminister, Irakli Garibasjvili, i november 2014, hvor han godt nok roste Georgiens imponerende fremskridt og betegnede Georgien som "en af vores mest engagerede partnere, som spiller en enestående rolle i vores (NATOs) operationer", men Stoltenberg havde ellers ikke andet end de pæne ord at tilbyde georgierne.

Generalsekretæren understregede, at NATO står ved Georgiens side, mens landet arbejder sig hen imod et medlemskab af Alliancen, og fremsatte garantier for, at Georgien bliver medlem af NATO, 
Når hverken EU eller NATO kan give Georgien klare tilsagn om medlemskab og ej heller give landet andre fordele, vil der før eller senere opstå en situation, hvor georgierne, både landets regering og befolkningen, må stille sig det klare spørgsmål, om landets stræben efter medlemskab af disse organisationer er den rette vej at gå.

forudsat landet opfylder de nødvendige kriterier. Hvorvidt Jens Stoltenberg selv tror på sine ord, skal man naturligvis ikke gøre sig klog på; men det er ganske sikkert, at NATOs måde at agere på ikke kan tolkes på anden måde end som Alliancens accept af Ruslands geopolitiske krav i Kaukasus.

\section{Hvorfor EU og NATO?}

Når hverken EU eller NATO kan give Georgien klare tilsagn om medlemskab og ej heller give landet andre fordele, vil der før eller senere opstå en situation, hvor georgierne, både landets regering og befolkningen, må stille sig det klare spørgsmål, om landets stræben efter medlemskab af disse organisationer er den rette vej at gå.

Hos den georgiske befolkning bliver spørgsmålet om den georgiske europæiske integration nemlig mødt med en sund skepsis. Argumenterne hertil har for det meste været af ganske logisk og praktisk karakter og henviser til Georgiens geografiske placering langt væk fra Europa, men tæt ved Rusland.

Det er derfor tvivlsomt, hvorvidt Georgiens medlemskab af EU og NATO fortsat har den samme støtte hos den georgiske befolkning, som det eksempelvis havde i 2008. Her, kort efter krigen med Rusland, viste en vejledende folkeafstemning om landets medlemskab af NATO, at medlemskabet af alliancen havde opbakning hos 77 pct. af georgierne.

\section{Stigende tegn på tvivl}

Georgiernes tvivl ser ligeledes ud til at afspejle sig hos de georgiske politikere, hvor de første tegn begynder at vise sig.

Medlem af den regerende koalition ledet af partiet Den Georgiske Drøm, Gogi Topadze, sætter således spørgsmålstegn ved, om landets integration i EU og NATO er mere fordelagtig for Georgien end et medlemskab af Den Eurasistiske Union og Georgiens orientering mod øst. Gogi Topadzes bemærkninger har foreløbigt resulteret i, at han er blevet stemlet som prorussisk, men det kan formentlig forventes, at samme type ytringer og tvivl vil tage til i den kommende tid.

Samme vinde blæser nemlig også fra oppositionsleder Nino Burjanadze, den tidligere nære allierede af Georgiens tidligere præsident Mikheil Saakasjvili. Burjanadze, som i dag er leder af oppositionspartiet Den Demokratiske Bevægelse - Forenet Georgien, er ganske realistisk omkring Georgiens eventuelle medlemskab af NATO og EU. Det anser hun i Georgiens nuværende situation for at være ganske utopisk, selvom hun tidligere i sin politiske karriere har været en klar fortaler for Georgiens vestlige integration.

Burjanadze tog senere en anden kurs og er ofte blevet kritiseret for sit angiveligt nære forhold til Rusland og den russiske præsident Vladimir Putin. Hendes nuværende budskab synes dog mere og mere at vinde indpas hos georgierne. Især på grund af de manglende resultater fra landets samarbejde med EU og NATO.

\section{Regeringens faldende opbakning}

De foreløbige første tegn på tvivl og utilfredshed i Georgien ser ud til at svække 
den tidligere så klare opbakning til det georgiske regerende parti Den Georgiske Drøm. Den regerende koalition har foreløbigt ikke været i stand til at indfri georgiernes forhåbninger om en bedre levestandard, og det er tvivlsomt, hvorvidt partiet vil kunne levere de ønskede resultater i fremtiden.

Den stigende utilfredshed afspejler sig i den seneste undersøgelse foretaget af International Republican Institute, som viser, at 55 pct. af georgierne mener, at Georgien 'bevæger sig i en forkert retning' mens kun 25 pct. mener, at Georgien 'bevæger sig i den rette retning.' Utilfredsheden får yderligere næring på grund af den georgiske valutas, lariens, faldende værdi. Den 31. marts kostede en dollar 2,23 lari, mens den i november kun havde en værdi af 1,76 lari. I samme periode er der registreret fald i den georgiske eksport på 26 pct., mens en årlig inflation er blevet opgjort til 23 pct.

De manglende resultater betyder, at Den Georgiske Drøm ifølge International Republican Institutes undersøgelse må notere sig en vælgertilslutning på blot 36 pct., sammenlignet med 50,8 pct. ved lokalvalget $\mathrm{i}$ juni 2014.

\section{Stigende utilfredshed}

Utilfredsheden har foreløbigt resulteret i en demonstration igangsat af den tidligere præsident Mikheil Saakasjvilis parti, Den Forenede Nationale Bevægelse, hvor mellem 10.000 og 30.000 mennesker, alt efter hvilken kilde opgør antallet af demonstranterne, deltog.

Alt tyder på, at demonstrationen er begyndelsen på en kommende tendens, som formentlig vil brede sig i takt med, at en forbedring af levestandarden og håndgribelige resultater af Georgiens associeringsaftale med EU udebliver. Det eneste den regerende koalition og partiet Den
Georgiske Drøm kan trøste sig med er, at partiet foreløbigt ikke har en seriøs politisk udfordrer, som er stærk nok til at true partiets position.

Den Georgiske Drøm skal dog handle, hvis partiet ønsker at fastholde sin ledende position i landet. Den georgiske premierminister Irakli Garibasjvili har da også varslet, at regeringen i samarbejde med landets nationalbank arbejder på en plan, som ifølge ham vil 'meget hurtigt forbedre situationen. Han indrømmede dog samtidig, ifølge Radio Free Europe, at Georgien vil blive nødt til at nedjustere planerne om en vækst på fem pct. i 2015, da denne vil blive væsentligt lavere.

\section{Risiko for destabilisering}

Den sårbare politiske situation i Georgien kan blive udnyttet af Rusland, som formentlig vil forsøge at sætte alle sejl til for at fremme sine interesser i landet. Aftalerne med Sydossetien og Abkhasien er sandsynligvis det første skridt på denne vej.

Det næste kan være en mere aktiv tilgang i selve Georgien. Landets labile politiske situation kan nemlig være et perfekt udgangspunkt for en stigende russisk støtte til russiskvenlige oppositionspolitikere og organisationer. Denne kan i første omgang resultere $i$ en destabilisering af den politiske situation i landet og efterfølgende $\mathrm{i}$, at Georgien sætter tempoet på landets EU- og NATO-integration ned.

I værste fald kan russiskvenlige kræfter $i$ landet få helt overtal. I sådan et scenario kan det tænkes, at Georgien for alvor vender sig mod landets store nabo mod øst.

Meget er på spil, og der er derfor en forholdsvis stor risiko for, at den politiske situation i Georgien er på vej mod mere usikre tider, da destabilisering af den politiske situation i landet formentlig vil stå ret højt på den russiske ønskeliste. 
Det mest stabile i den nuværende situation, og formentlig også under et destabiliseret Georgien er paradoksalt nok udbryderrepublikkerne Sydossetien og Abkhasien.

Ifølge tilgængelige informationer fra republikkerne er begge republikkers indbyggere tilfredse med den aktuelle udvikling. En del af samarbejdsaftalen med Rusland er også en stigning af lokale overførselsindkomster til russisk niveau, og det er formentlig de færreste, der kan have noget imod.

Situationen i Sydossetien og Abkhasien er langtfra noget, der kan betegnes som en frossen konflikt, uanset hvilke øjne man ser på problematikken med på. Sydossetien og Abkhasien ser ud til fortsætte sin prorussiske udvikling og tætte forbindelser til Rusland ganske upåvirket, uanset hvad der måtte ske i Georgien.

Det er formentlig derfor også kun et spørgsmål om tid, hvornår man i Georgien og Vesten må indse, at konflikten omkring republikkerne ikke længere kan betegnes som en frossen konflikt, og at republikkerne mere eller mindre er tabt. 